\title{
BYZANTINE HYMNOGRAPHY AS THE SOURCE OF THE DOCTRINE OF DIVINE ENERGY IN THE THEOLOGY OF HIEROSCHEMAMONK ANTHONY (BULATOVICH) ${ }^{1}$
}

\author{
Tatyana A. Senina (nun Kassia) \\ Sociological Institute of Russian Academy of Sciences - Branch of Federal Research Centre for Sociology \\ of Russian Academy of Sciences, Saint Petersburg, Russian Federation
}

\begin{abstract}
Introduction. This work is intended to examine the use and interpretation of Byzantine hymnographic texts of Hieroschemamonk Anthony (Bulatovich), who was the leader of the Athonite Onomatodoxists during the 1910s, written during his defence of the Palamite doctrine on divine energy.

Methods. Source research and analysis, philosophical hermeneutics and comparative textological research are the methods used in this work. Sources on the subject include the works by Anthony (Bulatovich), Gregory of Nazianzus, Cyril of Alexandria, Dionysius the Areopagite, and Gregory Palamas.

Analysis. In his dispute about the name of God, Bulatovich paid much attention to the theme of divine energies. The doctrine on energy of God, developed by the Church Fathers and especially Gregory Palamas, was important for Bulatovich since he considered divine revelation to be an uncreated energy of God. He believed the name of God to be an example of such a revelation and therefore, being by essence energy of God, he argued that God's name is God. Onomatodoxy skeptics claimed, in contrast to Palamas, that divine energy cannot be viewed as God. Bulatovich aimed to prove the opposite and, not having many patristic writings at his disposal, he looked for confirmation of Palamite teachings on divine energy in biblical and hymnographic texts.

Results. An analysis of hymnographic quotes used by Bulatovich shows that he understood their theological meaning correctly and derived ideas developed by Church Fathers from hymnography. Byzantine hymnography served Bulatovich as the main source of the Orthodox Church's dogmatics.

Key words: religious philosophy, Russian theology, Byzantine theology, Orthodoxy, hymnography, onomatodoxy, palamism.

Citation. Senina T.A. (nun Kassia). Byzantine Hymnography as the Source of the Doctrine of Divine Energy in the Theology of Hieroschemamonk Anthony (Bulatovich). Vestnik Volgogradskogo gosudarstvennogo universiteta. Seriya 4, Istoriya. Regionovedenie. Mezhdunarodnye otnosheniya [Science Journal of Volgograd State University. History. Area Studies. International Relations], 2018, vol. 23, no. 5, pp. 60-70. (in Russian). DOI: https://doi.org/10.15688/jvolsu4.2018.5.5
\end{abstract}

\section{ВИЗАНТИЙСКАЯ ГИМНОГРАФИЯ КАК ИСТОЧНИК УЧЕНИЯ О БОЖЕСТВЕННОЙ ЭНЕРГИИ В БОГОСЛОВИИ ИЕРОСХИМОНАХА АНТОНИЯ (БУЛАТОВИЧА) ${ }^{1}$}

\section{Татьяна Анатольевна Сенина (монахиня Кассия)}

Социологический институт РАН - филиал Федерального научно-исследовательского социологического центра, г. Санкт-Петербург, Российская Федерация

Аннотация. В споре о почитании имени Божия лидер афонских имяславцев иеросхимонах Антоний (Булатович) уделил много внимания теме божественных энергий. Учение об энергии Божией, разработанное 
отцами Православной Церкви и более всего св. Григорием Паламой, было важно для Булатовича, поскольку он подчеркивал, что божественное Откровение является божественной энергией, а имя Божие есть частный случай этого Откровения. Таким образом, если энергия Божия есть сам Бог, то можно называть Богом и Его богооткровенные имена. Противники имяславия утверждали, в противоположность св. Григорию, что энергию Божию нельзя называть Богом и что имяславцы неправильно понимают церковное учение об энергии Божией. Булатович стремился доказать обратное и, поскольку в его распоряжении не было ни сочинений самого Паламы, ни значительной части тех святоотеческих сочинений, которыми пользовался св. Григорий, о. Антоний искал подтверждение паламитскому учению об энергии Божией в библейских и гимнографических текстах. Анализ гимнографических цитат, использованных о. Антонием в полемике, показывает, что он верно понял их богословский смысл и почерпнул из церковного богослужения идеи, разработанные в византийской патристической традиции и выраженные у таких отцов Церкви, как Григорий Богослов, Кирилл Александрийский, Дионисий Ареопагит и Григорий Палама: учение о различии сущности и энергии в Боге, о нетварности божественных энергий, о единстве воли и действия Лиц Св. Троицы, о действии Бога на тварь через энергии, о возможности для человека причаститься божественному свету-энергии. Таким образом, византийская гимнография послужила для Булатовича источником догматического учения Православной Церкви.

Ключевые слова: религиозная философия, русское богословие, византийское богословие, православие, гимнография, имяславие, паламизм.

Цитирование. Сенина Т. А. (монахиня Кассия). Византийская гимнография как источник учения о божественной энергии в богословии иеросхимонаха Антония (Булатовича) // Вестник Волгоградского государственного университета. Серия 4, История. Регионоведение. Международные отношения. - 2018. - Т. 23, № 5. - C. 60-70. - DOI: https://doi.org/10.15688/jvolsu4.2018.5.5

Введение. Богословское наследие иеросхимонаха Антония (Булатовича) уже становилось предметом исследований (см.: [8, с. $405-454 ; 9$, с. $21-49 ; 17 ; 18 ; 19 ; 20 ; 26 ; 27])$, однако не все его аспекты изучены одинаково хорошо. Цель данной статьи - проанализировать использование и истолкование о. Антонием византийских гимнографических текстов в ходе отстаивания паламитского учения о божественной энергии и выяснить, какие патристические идеи Булатович в них почерпнул. В предыдущих исследованиях этой теме уделялось мало внимания, между тем использование богослужебных текстов в качестве источника догматического предания представляет особенный интерес, поскольку в ученом богословии дореволюционной поры не было принято приводить в качестве доводов данные гимнографии.

Методы. В основу работы положен метод аналитического исследования источников, проясняющий их логику и содержание. Для интерпретации рассматриваемого материала использовались методы философской герменевтики и сравнительно-текстологического анализа.

Источники по теме включают богословские работы Булатовича, тексты византийской гимнографии («Октоих») и сочинения отцов Православной Церкви: Григория Богосло- ва (Слова и стихотворения), Кирилла Александрийского («Диалоги о Святой Троице»), Дионисия Ареопагита («О божественных именах») и Григория Паламы («Триады в защиту священно-безмолвствующих» и «Опровержения Акиндина»). При анализе соответствия учения Булатовича богословию отцов-каппадокийцев, Паламы и других отцов Церкви использованы патрологические исследования И. Мейендорфа, В.М. Лурье, Д.С. Бирюкова.

Специальных научных работ об использовании Булатовичем в своем богословии гимнографических текстов нет. Лишь несколько случаев такого использования упомянуты в книге епископа Илариона (Алфеева) и монографии Т.А. Сениной. В обоих исследованиях отмечено активное применение Булатовичем гимнографических текстов для обоснования своих богословских взглядов и указано, что данное явление заслуживает интереса и дальнейшего исследования. Зарубежные исследователи эту тему не изучали.

Анализ. Иеросхимонах Антоний (Булатович), главный защитник афонского имяславия, указывал, что между конфликтом из-за учения об имени Божием в 1910-х гг. (см.: [17; 8 , с. $289-637$; 9, с. $21-137$; 18, с. 9-25, 52-106, 168-172]) и богословским спором св. Григория Паламы с Варлаамом Калабрийцем в XIV в. (см.: [11, с. 327-460]) много общего: 


\section{ВИЗАНТИЙСКОЕ НАСЛЕДИЕ}

от вопросов, связанных с Иисусовой молитвой, обе дискуссии перешли к теме божественных энергий [3, с. 203]. Отталкиваясь от церковной анафемы против Варлаама, о. Антоний уже в своей первой книге [1] начал строить защиту имяславия исходя из того, что Церковь признала божественность всякого действия (энергии) Бога, а значит и имена Божии, будучи богооткровенными, являются действием Божиим по внутренней своей сути ${ }^{2}$ и имеют божественный статус (см.: [26; 27 , p. 405-409; 18, с. 193-196]). Поэтому, согласно Булатовичу, отрицающие божественность имен Божих и обвиняющие имяславцев в двубожии ${ }^{3}$ подпадают под анафему против Bapлаама [1, с. 2-4].

Противники имяславия действительно показали себя приверженцами варлаамитской ереси: в послании Синода 1913 г. по поводу имяславия и в докладах архиепископов Антония (Храповицкого) и Никона (Рождественского), а также С.В. Троицкого, которые стали основой для послания, прямо сказано, что энергию Божию нельзя называть Богом, - как это утверждал и Варлаам, в противоположность Григорию Паламе и учению, утвержденному на Константинопольском соборе в 1351 г. (см.: [16, с. 42-43, 48, 60-62, 68-69, 77, 90-92, 119-121, 143-144; 17, c. 1015-1030; 18, c. 173177]). Можно дискутировать о том, было ли это одобрение ереси сознательным актом или следствием невежества. Русские академические богословы почти не интересовались паламитской проблематикой и, соответственно, не имели верного представления о церковном учении о божественной энергии (см.: [19, c. 117-118, 122]). Эта тема впервые столь громко зазвучала в русском богословии именно у о. Антония (Булатовича).

В «Апологии веры во Имя Божие и во Имя Иисус» о. Антоний почти не развивал тему божественных энергий, поскольку, узнав об анафеме на Варлаама, был уверен, что Церковь давно утвердила учение о божественности всякого действия/энергии Божией. Но когда противники имяславия и сам Синод стали утверждать, что имяславцы плохо поняли учение Церкви и что энергию Божию нельзя называть Богом, Булатовичу пришлось обратить более пристальное внимание на данную тему. Поскольку имя Божие богооткровенно и является частным случаем «Глагола Божия», то, по мысли Булатовича, для доказательства его божественности нужно было обосновать божественность всякого действия Бога, в том числе всякой богооткровенной истины (см.: [2, с. 5]).

Главное затруднение защитников имяславия состояло в том, что у них не было возможности ознакомиться с деяниями собора 1351 г. и сочинениями Паламы, еще не изданными в то время. В распоряжении Булатовича не было не только сочинений Паламы, но и значительной части тех источников, которыми пользовался св. Григорий (см.: [18, с. 139-144]); доступ к сочинениям отцов Церкви вообще был затруднен для отца Антония из-за болезни глаз и стесненных условий жизни после изгнания с Афона. Поэтому он опирался прежде всего на тексты библейские и богослужебно-литургические и справился с задачей, по сути заново отыскав подтверждение церковному учению об энергиях Божиих (см.: [27; 20; 18, с. 179-213, 227269]). Этому посвящена прежде всего его книга «Моя мысль во Христе. О Деятельности (Энергии) Божества» - наиболее важное и самобытное богословское сочинение Булатовича. В начале этой работы он пишет:

Энергия Божия - значит Деятельность Существа Божия. Как мы знаем, Варлаам первоначально отрицал существование у Бога Деятельности (Энергии), потом стал утверждать, что Существо Божие и Деятельность Божия есть то же самое, но Святой Григорий Палама установил, с одной стороны, неслитность Деятельности Божией с Существом Божиим, а с другой стороны нераздельность Деятельности Божией от Существа Божия и Божеское достоинство и Божескую природу Деятельности Божества. Под Энергией - «Деятельностью» Божества понимается преимущественно внешнее проявление Деятельности Божества по отношению к твари. О этой Энергии и будет идти речь в сей книге. <...> Деятельность Самого Божества, обращенная к людям по создании, сия Деятельность или Энергия Божества, в Глаголах Божественного Откровения деющая, была тем умным Светом, который просвещал умы человеческие и до грехопадения в величайшей степени, и по грехопадении не окончательно угас: «И Свет во тьме светится и тьма Его не объят» (Ин. 1:5) [2, с. 6-7, 9].

Отец Антоний не читал догматических сочинений Григория Паламы и сумел само- 
стоятельно выразить его учение о причастии недоступного по сущности Бога через Его энергии, которые, не будучи сущностью, являются тем не менее тем же самым Богом:

Как мы различаем, но не разделяем Три Лица Святой Троицы, так мы различаем от существа Триединой Троицы Ее Триединую Деятельность, но отнюдь не отделяем ее от Существа Божия, посему и вправе и должны как про Существо Божие, так и про Энергию Божию говорить - «Бог». Вернее же говорить: «Сам Бог» - именно в смысле соприкосновения в Деятельности с Самим Богом. Ибо в Деятельности Божества не какое-либо иное Божество почитается, отдельное от Святой Троицы, но Сама Святая Троица в проявлении Деятельности Своей [2, с. 53] (ср.: [11, с. 288-300]).

Божественную энергию/деятельность о. Антоний называл «триединой», указывая, что все Лица Троицы обладают одной энергией, но при этом «каждое Лицо имеет свойственную Ему долю участия в едином общем действии» [2, с. 18] (ср.: [2, с. 13-14, 17, 19, 37]). Уже отмечалось, что данная богословская идея вписывается в рамки традиционного святоотеческого учения о единой, но и троичной энергии Бога (см. подробнее: [18, с. 186-193]).

До начала времен «действие Божие было обращено к Самому Богу» [1, с. 4] и было «созерцанием Самого Себя» $[1, \text { с. } 30]^{4}$, а затем Бог обратил свою энергию к сотворению мира:

Всеблаженный и вседовольный Бог присно самодовлеет в движении взаимной любви прежде бытия всякой твари.

Но вот, Всеблагий Бог благоизволил по преизбытку Свой благости, дабы осчастливить и еще некие существа участием в Его преизбыточествующей любви и блаженстве, благоволил создать словесную тварь, - сначала Ангелов, а потом человеков, - и открыть Себя сей твари, дабы и ее приобщить к любви Своей и к Божеству Своему. С этого момента обратился Бог Деятельностию Своею и к твари. Так, во-первых, сотворил Бог землю и небо в жилище словесной твари. Отец начало Тройственному Произволению положил, Сын волю Божию в Глаголе определил, а Дух Святый совершил, и мир из небытия в бытие приведен был тройственным действием Божества, как о том свидетельствует Слово Божие: «Словом Господним небеса утвердишася, и Духом уст Его вся сила их» (Пс. 32:6) [2, c. 14].
Сравним со св. Григорием Богословом:

Но поелику для Благости не довольно было упражняться только в созерцании Себя самой, а надлежало, чтобы благо разливалось, шло далее и далее, чтобы число облагодетельствованных было как можно большее, ибо сие свойственно высочайшей Благости, то Бог измышляет, во-первых, ангельские и небесные силы. И мысль стала делом, которое исполнено Словом и совершено Духом. <..> Поелику же первые твари были благоугодны Богу, то измышляет другой мир - вещественный и видимый... (Слово 45, 5-6 [13, с. 561]).

...приступим уже к изложению богословия. Управлять же словом предоставим Отцу и Сыну и Святому Духу, о Которых у нас слово, - Отцу, да благоволит о нем, Сыну, да содействует ему, Духу, да вдохнет его; лучше же сказать, да будет на нем единого Божества единое озарение, соединительно разделяемое и разделительно сочетаваемое, что и выше разумения! (Слово 28, 1 [13, с. 333]).

Отец Антоний был знаком с сочинениями Григория Богослова, хотя и неясно, в каком объеме, но при рассуждении о божественном действии не ссылается на него ${ }^{5}$, а находит подтверждение учению о триединой энергии Божией, сотворившей мир, в гимнографических текстах:

...как свидетельствует Церковь: «В начале небеса всесильным Словом утверждей, Господи Спасе, и вседетельным и Божиим Духом всю силу их» (Ирмос 7-го гласа ${ }^{6}$, песнь 3-я). - В этих стихах упоминается только о участии Сына и Духа Святаго Деятельностями Их в миротворении, но естественно подразумевается и участие Отца, как Инициатора, как Родителя Слова, как Изводителя Духа Святаго, Деятельностию первого Произволения Своего, о чем и гласят церковные песнопения, как мы увидим ниже [2, с. 14].

Далее Булатович посвящает этому целую главу II, «Указания Св. Писания и Предания на тройственную Деятельность Божества» [2, с. 21-39]. Под «Преданием» о. Антоний подразумевает здесь тексты церковного богослужения. Булатович находит там указание на равенство по действию между Лицами Св. Троицы:

Во втором антифоне 6-го гласа говорится: «Святым Духом обожение всем, благоволение, разум, мир и благословение: Равнодетелен ${ }^{7}$ бо есть 


\section{ВИЗАНТИЙСКОЕ НАСЛЕДИЕ}

Отцу и Слову». Слова «Равнодетелен Отцу и Слову» совершенно непреложно означают, что Святой Дух имеет равное участие в общей деятельности Святой Троицы наравне с участием в сей деятельности Отца и Слова.

Троичность и триединство Действия Божества свидетельствуются следующими словами Троичного канона 1-го гласа (см. песнь $6^{8}$ ): «Равностатную силу яко имущи, Троице пресущественная, в тождестве хотения, единица еси проста и нераздельна, Ты убо нас силою Твоею соблюди». - Итак, следовательно, здесь говорится о том, что Сила, то есть Деятельность или Энергия Святой Троицы у всех трех Лиц есть Равностатна. Триедина есть Сила Святой Троицы и равное участие в силе каждого действия Святой Троицы принимают все три Лица. И хотение Святой Троицы - триедино, ибо каждая Ипостась, как совершенное Лицо, не лишено собственной воли и хотения, но тем не менее у всех трех Лиц - одна воля, одно хотение, по тождеству сего хотения. Волитель всякого хотения Божия есть Отец, Сын же и Дух Святой волею и хотением Своим хотят и волят всесовершенно то, что волит и хочет Отец. Таким образом, соблюдается единство и простота, и неделимость Деятельности Божества [2, c. 21-22].

Говоря о божественной энергии, Булатович из гимнографических сочинений цитирует церковно-славянский перевод «Октоиха» [12], чаще всего Троичные каноны для воскресной полунощницы, написанные византийским гимнографом IX века Митрофаном, архиепископом Смирнским. Если мы обратимся к греческому тексту процитированных о. Антонием произведений, то найдем в упо-

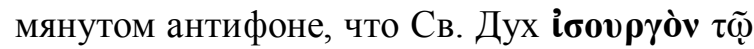

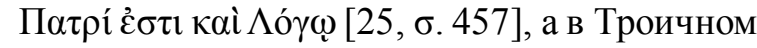

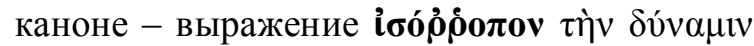

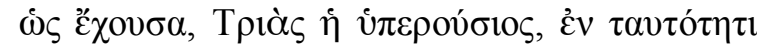

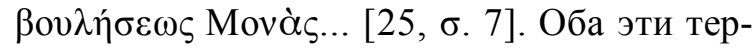

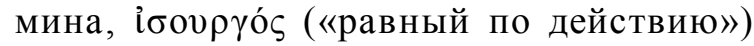

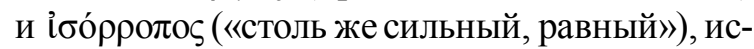
пользует св. Кирилл Александрийский, например, в Диалогах о Святой Троище, говоря о равенстве Лиц Троицы, в том числе по действию (см.: [23, vol. II, p. 360.18-23]; ср.: [23, vol. II, p. 318.43-48, vol. III, p. 116.1-2, 210.35212.39, 224.6]) (см. также: [24, p. 677-678]).

Затем Булатович цитирует 1-й тропарь из 7-й песни того же канона: «Слове Божий, соестественное Сияние Вседержителя Бога, якоже обещал еси еже у Тебе, богодетельное

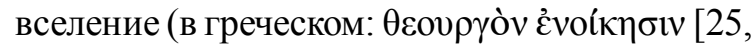

б. 7]) сотвори, яко благоутробен, со Отцем Твоим и Духом, и страшна бесом мя покажи и страстем», - и поясняет: ““Богодетельное вселение” значит - вселение Божеской “Детели", то есть Энергии, которая есть триединое соестественное Сияние Света Трисолнечного Божества» [2, с. 22]. Подобных примеров много в «Моей мысли во Христе»: везде в церковных песнопениях, где встречаются выражения «трисветное едино Божество», «Светодетель», «Трисвете Боже», «Светолучные блистания», «Солнца лучи трисиянного светодетельныя», «трисиятельное единоначалие Божества» и т. п., Булатович справедливо видит указание на божественную энергию Бога-Троицы, озаряющую тварь (см.: [2, с. 25-35]).

Отец Антоний приводит 3-й тропарь из 5-й песни Троичного канона 5-го гласа: «Свет нераздельный единаго Естества, разделенный начертаньми, трисиянный, невечерний (в гре-

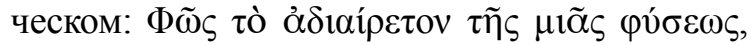
$\mu \varepsilon \mu \varepsilon \rho \imath \sigma \mu \varepsilon \dot{v}$ ov $\tau$ o ${ }_{\zeta} \chi \alpha \rho \alpha \kappa \tau \tilde{\eta} \rho \sigma \mathrm{l}, \tau \rho \imath \lambda \alpha \mu \pi \grave{\varepsilon} \zeta$,

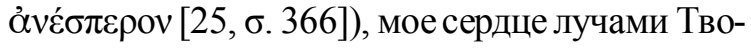
ими озари», - и толкует его так:

Церковь обращается прямо к Энергии Божества, именуя сию Энергию «Светом нераздельным единаго Естества». - Очевидно, что Существо Божие именуется здесь «Естеством», а «Свет» сего Божественного «Естества» есть, несомненно, Его Энергия, к которой и направлено наше моление. Затем мы видим, что сия Энергия Естества Божия именуется «Светом Трисиянным», то есть тройственным, и «Разделенным начертаньми», то есть неслитным, который, хотя и единствен в действии Своем, но имеет в себе долю участия каждого Лица в триединой Энергии. Наконец, именуется «Невечерним», то есть вечным и неизменным, ибо Деятельность Божия так же вечна, как вечно и Существо Его [2, с. 23-24].

Сходным образом о. Антоний находит указание на различие сущности и энергии Божией и в других гимнографических сочинениях. Например, толкуя 2-й тропарь 5-й песни Троичного канона 4-го гласа на воскресной полунощнице, по поводу выражения «несозданное Естество и светодейственный Источниче всякия Светодетельныя зари» Булатович пишет:

Здесь совершенно определенно делается различие между непричастимою Сущностью Божества 
и причастимою Его Энергиею: Существо Божие именуется - «Свет Трисолнечный, Существенный Свет, Единственное Божество, Несозданное Естество и Светодейственный Источник», а Энергия Божества именуется Светодательною Зарею сего Светодейственного Источника - Существа Святой Троицы. Также изъявляется, что в причастии сих Лучей Света Божества созерцается неизреченная Доброта Божества, то есть Его совершенства» [2, c. 34-35].

Таким образом, Булатович черпает из гимнографии православное учение о божественной сущности и изливающейся из нее на тварь энергии-свете, которое наиболее ярко выразил Григорий Палама, говоря, что божественная нетварная энергия есть «свет будущего и неизменного века, общее упование благочестивых, светлость божественной природы, справедливейше именуемая божеством (потому что она паче всего есть боготворящий дар, ибо сообразно с ней "праведники просияют, как солнце”, “Бог коих будет посреди богов”, раздавая награды тамошнего блаженства), <..> свет, именуемый божеством и светлостью божественной природы, но не природой» (Второе опровержение Акиндина, 5.14 [15, с. 100]).

Отмечу, что св. Григорий, богословствуя о божественном свете, приводит в качестве аргументов цитаты не только из святых отцов, но и из церковных песнопений - см., например, Триады, I.3.29, II.3.53, III.1.12, 15, 16, 17, 19, 20, 23, III.3.9 [6, c. 92, 239, 278, 280-284, 287, 336-337] или Первое опровержение Акиндина, 7.25 [15, с. 47-48 9 $]$ ), - называя их «святым преданием» (Tpuadbl, II.3.29 [6, c. 216]). В точности так же поступает и Булатович. Византийцы привыкли выражать богословские идеи, используя литургический символизм, «на языке богослужения Небесного Храма» (см.: [10;22]). Таким образом, использование гимнографических текстов о. Антонием лежит в русле византийской традиции.

Вот еще пример того, как о. Антоний находит в гимнографических текстах указание на возможность причастия божественной энергии-свету, вновь богословствуя в духе Григория Паламы:

В Троичном каноне 2-го гласа говорится: «Иже Источник и корень Отец сый, яко виновен, иже в Сыне и Святем Дусе срасленнаго Божества Трисолнечный сердиу моему источи Свет, и причастием осияй Богодетельнаго Сияния» (песнь 1, троп. 2). Итак, здесь ясно приносится прошение о том, чтобы Бог сподобил бы причастить молящихся причащением Энергии Божества, которая именуется «Богодетельным Сиянием Трисолнечнаго Света».

В том же каноне говорится еще: «Трисветлая Единице Богоначальная, весь разори грехов и страстей моих мрак, Светлых Лучей Твоих сладчайшими Причащеньми, и сотвори мя Твоея неприступныя Славы храм и сень пречистую» (п. 1, тр. 3).Итак, как видите, здесь опять-таки изъявляется причастимость Энергии Божества, которая именуется «Светлыми Лучами» и «Неприступною Славою», то есть Славою Неприступного Бога [2, с. 31-32] (cp.: [2, c. 33]).

По поводу выражения «Едино Царство и Господство» из троичного тропаря, поемого на воскресной полунощнице после канона, о. Антоний пишет: «"Царство" и “Господство" суть именования Энергии Божества» [2, с. 24]. Здесь он мыслит согласно со св. Дионисием Ареопагитом ${ }^{10}$, который, говоря о том, что неименуемый по сущности Бог именуется по Своим действиям и силам $(O$ божественных именах, 1.4-6 [7, с. 219-237]), упоминает среди божественных имен и эти, поясняя, что имя «Царство» обозначает деятельность Бога по «распределению всяких ограничений, постановлений, законов и порядков» для твари, а «Господство есть не только преодоление худшего, но и всесовершенное овладение всяким добром и благом и их истинное и надежное обеспечение» (там же, 12.2 [7, с. 545]). В учении Булатовича о божественных именах как выражении свойств и энергий Бога много параллелей с богословием Ареопагита. Отец Антоний не был знаком с его творениями, но сумел выразить то же учение, опираясь, опятьтаки, на библейские и богослужебные тексты (см. подробнее: [18, с. 248-263]).

Сходным образом Булатович истолковывает и понятие божественной «державы». Он цитирует 1-й тропарь 1-й песни Троичного канона 5-го гласа: «Державу единственнаго и трисолнечнаго зрака (в греческом: Кра́то $\tau \tilde{\eta} \varsigma$

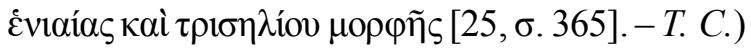
воспевающе, вопием: ум наш озари, Боже Всесильный, и к Твоей, Владыко, возвыси славе неизреченней», - и пишет: 


\section{ВИЗАНТИЙСКОЕ НАСЛЕДИЕ}

Итак, мы видим, что Церковь воспевает «Державу» Божию, именуя этим Энергию Божества, ибо Держава Божия есть державная Деятельность Его. Затем мы видим, что сия Энергия Божия именуется «Державой единственнаго и трисолнечнаго зрака». - Этими словами исповедуется тройственность Деятельности Божества, в коей каждое Лицо имеет долю Своего участия в единстве Действия, то есть как бы в одном озарении тремя солнцами. Свет сих трех солнцев окажется един, но каждое солнце будет иметь долю своего участия в едином озарении. Затем молитва о озарении нашего ума трисолнечным Светом являет то, что озарение нашего ума Божественными откровениями и лучами Богоразумия есть всецело плод непосредственной таинственной Деятельности Божества [2, с. 24-25] (cp.: $[2$, c. 28$]$ ).

\section{Сравним с Григорием Богословом:}

В трех Светах одно естество неподвижно. Единица не бесчисленна, потому что покоится в трех Добротах. Троица не в разной мере досточтима, потому что естество не рассекаемо. В Божестве Единица, но тричисленны Те, Которым принадлежит Божество. Каждый есть единый Бог, если именуешь одного. И опять, един Бог безначальный, из Которого богатство Божества, когда слово упоминает о Трех. < ..> ...у моей Троицы одна сила, одна мысль, одна слава, одна держава; а чрез сие не нарушается и единичность, которой великая слава в единой гармонии Божества. Сие только свету, который во мне, открыло Троичное сияние из-за воскрилий завесы внутрь Божия храма, за которыми сокрыто царственное естество Божие (Стихотворения Богословские, I.1.1: О Святом Духе [14, c. 15-16]).

Вот еще пример того, как о. Антоний осмысливает богословские выражения из гимнографических текстов:

Святая Троица называется в церковных песнопениях: «Единоначальная, Живоначальная, Светоначальная». Что же означают сии названия? «Единоначальная» означает Единое начало всякого действия Божия. «Единоначальная» значит также и то, что сим исповедуется, что Деятельность Божества не есть тварь, ибо Бог в Троице именуется не Творцом Своей Деятельности, но Началом.

«Живоначальная» Троица означает, что Она есть «Начало» Жизни Вечной и вообще начало Духа Жизни Божественной. Сей «Дух Жизни» есть сила, исходящая из Святой Троицы, как из своего Начала, то есть сей Дух Жизни есть жизненная Деятельность Св. Троицы.
Наконец, Святая Троица называется «Светоначальная», и этим самым признается то же самое, что Свет Истины Божественной, а следовательно, и тот Свет, который сокровен в Глаголах Божиих, есть Деятельность Света Истины Божества, ибо исходит из Пребожественной Троицы, как из Своего начала, а не сотворен подобно разным другим тварным силам [2, с. 30].

У отцов-каппадокийцев «единоначалие» Бога означало прежде всего «монархию» Отца как единого Начала в Троице, однако при этом всегда подчеркивалось полное равенство Лиц по природе и действию: хотя Сын и Дух имеют началом Отца, они, тем не менее, безначальны и бесконечны в отношении времени, поскольку так же вечны, как Отец и не появились позже Него (см.: [4, с. 296-299; 5, с. 316320]). Тем не менее, толкуя слово «Единоначальный» (греч. $\mu$ о́v $\alpha \chi \propto \varsigma)$ как указующее на Троицу как «единое начало всякого действия Божия», о. Антоний не выпадает из церковной традиции, поскольку «единоначалие» ( $\mu$ ov $\alpha \rho i \alpha)$ в Троице означает также и полное единство воли и действия в творении и управлении миром (см.: [24, р. 877]). Св. Григорий Богослов, говоря о единоначалии Бога, подчеркивает: «...мы чтим единоначалие... которое составляет равночестность единства, единодушие воли, тождество движения и направления к единому Тех, которые из Единого, что невозможно в естестве сотворенном, так что Они, хотя различаются по числу, но не разделяются по власти» (Слово 29, 2 [13, с. 351-352]).

Выводы. Анализ гимнографических цитат, использованных о. Антонием, показывает, что он в целом верно понимал их богословский смысл и почерпнул из церковного богослужения богословские идеи, разработанные в византийской патристической традиции и выраженные у таких отцов Церкви, как Григорий Богослов, Кирилл Александрийский, Дионисий Ареопагит и Григорий Палама, чьи произведения, за небольшим исключением, Булатович не имел возможности прочесть в ходе имяславческой полемики. Это учение о различии сущности и энергии в Боге, о нетварности божественных энергий, о единстве воли и действия Лиц Св. Троицы, о действии Бога на тварь через энергии, о возможности для человека при- 
частиться божественному свету-энергии. Таким образом, византийская гимнография послужила для о. Антония важным источником догматического учения Православной Церкви.

\section{ПРИМЕЧАНИЯ}

1 Исследование выполнено приподдержке Российского научного фонда, проект № 18-18-00134 «Наследие византийской философии в русской и западноевропейской философии XX-XXI вв.».

The research has been funded by the Russian Science Foundation, project 18-18-00134 "The heritage of Byzantine philosophy in twentieth and twenty-first century Russian and Western European philosophy".

${ }^{2}$ Материальные буквы и звуки, которыми выражаются имена, Булатович божественной энергией и Богом никогда не считал и приравнивал к иконам (см.: [18, с. 229-236, 272-274]).

3 То есть в почитании имени Божия как второго Бога. Такое обвинение содержалось в имяборческой рецензии на книгу схимонаха Илариона «На горах Кавказа», написанной иноком Хрисанфом (Минаевым) (см.: [16, с. 16; 9, с. 104-107]). С появлением этой рецензии и начался на Афоне спор об имени Божием.

${ }^{4}$ Булатович цитирует здесь св. Иоанна Дамаскина, см.: Точное изложение православной веры, II, 2 (16) [21, с. 187].

5 В книгах Булатовича есть лишь несколько цитат из его Слов $[1$, с. $32 ; 3$, c. 15,106$]$, и они касаются не божественных энергий, а других вопросов.

${ }^{6}$ Имеется в виду ирмос канона на утрени из Октоиха.

7 Здесь и далее в цитатах выделено Булатовичем.

8 Отец Антоний цитирует 1-й тропарь песни.

9 Между прочим здесь Палама, подобно Булатовичу, цитирует среди прочего один из Троичных канонов Митрофана.

10 Так я называю, по церковной традиции, неизвестного автора корпуса Ареопагитик.

\section{СПИСОК ЛИТЕРАТУРЫ}

1. Антоний (Булатович), иеросхимонах. Апология веры во Имя Божие и во Имя Иисус / А. Булатович. - М. : Печ. А. И. Снегиревой, 1913. - XIV, 189 с.

2. Антоний (Булатович), иеросхимонах. Моя мысль во Христе. О Деятельности (Энергии) Божества / А. Булатович. - Пг. : Исповедник, 1914. - 248 с.

3. Антоний (Булатович), иеросхимонах. Оправдание веры в Непобедимое, Непостижимое,
Божественное Имя Господа нашего Иисуса Христа / А. Булатович. - Пг. : Исповедник, 1917. - 232 с.

4. Бирюков, Д. С. Св. Григорий Богослов. Триадология и антиарианская полемика / Д. С. Бирюков // Антология восточно-христианской богословской мысли. Ортодоксия и гетеродоксия. Т. 1 / сост., ред. Г. И. Беневич ; ред. Д. С. Бирюков. - М. ; СПб. : Никея, РХГА, 2009. - С. 291-301. - (Smaragdos Philocalias ; Византийская философия ; 4)

5. Бирюков, Д. С. Св. Григорий Нисский. Полемика с Евномием / Д. С. Бирюков // Антология восточно-христианской богословской мысли. Ортодоксия и гетеродоксия. Т. 1 / сост., ред. Г. И. Беневич ; ред. Д. С. Бирюков. - М. ; СПб. : Никея : РХГА, 2009. - С. 315-322. - (Smaragdos Philocalias ; Византийская философия ; 4).

6. Григорий Палама. Триады в защиту священно-безмолвствующих / пер., послеслов. и коммент. В. Вениаминова. - М. : Канон, 1995. - 384 с. (История христианской мысли в памятниках).

7. Дионисий Ареопагит. Сочинения ; Максим Исповедник. Толкования. - СПб. : Изд-во Олега Абышко, 2002. - 864 с. - (Библиотека христианской мысли. Источники).

8. Иларион (Алфеев), епископ. Священная тайна Церкви. Введение в историю и проблематику имяславских споров. Т. I / И. Алфеев.- СПб. : Алетейя, 2002. -653 с.

9. Лескин, Д., священник. Спор об имени Божием. Философия имени в России в контексте афонских событий 1910-х гг. / Д. Лескин. - СПб. : Алетейя, 2004. - 368 с. - (Византийская библиотека. Исследования).

10. Лурье, B.M. Theophaneia School : Экфрасис Небесного Храма / В.М. Лурье // Scrinium. Revue de patrologie, d'hagiographie critique et d'histoire ecclésiastique. T. 3. -2006. - P. ix-xii. - DOI: https://doi.org/10.1163/18177565-90000147.

11. Мейендорф И. Жизнь и труды святителя Григория Паламы / И. Мейендорф. - СПб. : Византинороссика, 1997. - XVI, 480 с. - (Subsidia Byzantinorossica; 2).

12. Октоих, сиречь Осмогласник. Т. 1. Гласы 14. - М. : Талан, 1981. - 712 с. ; Т. 2. Гласы 5-8. - М. : Талан, 1981. -672 c.

13. Святитель Григорий Богослов, архиепископ Константинопольский. Творения. В 2 т. Т. І. Слова. М. : Сибирская благозвонница, 2010. - 895 с. - (Полное собрание творения святых отцов Церкви и церковных писателей в русском переводе ; 1).

14. Святитель Григорий Богослов, архиепископ Константинопольский. Творения. В 2 т. Т. ІІ. Стихотворения. Письма. Завещание. - М. : Сибирская благозвонница, 2011. - 944 с. - (Полное собрание творения святых отцов Церкви и церковных писателей в русском переводе ; 2). 


\section{ВИЗАНТИЙСКОЕ НАСЛЕДИЕ}

15. Свт. Григорий Палама, архиепископ Фессалоникийский. Полемика с Акиндином / Свт. Григорий Палама, архиепископ Фессалоникийский ; изд. подг. А. Г. Дунаев. - Святая Гора Афон : Издание пустыни Новая Фиваида, 2009. - 270 с. - (इМАРАГ О $\Sigma$ ФI $\Lambda \mathrm{OKA} \Lambda \mathrm{IA} \Sigma)$.

16. Святое Православие и именобожническая ересь. - Харьков : Епарх. тип., 1916. - IV, 278, XLII с.

17. Сенина, Т. Имяславцы или имябожники? : Спор о природе Имени Божия и афонское движение имяславцев 1910-1920-х годов. Т. II / Т. Сенина // Имяславие : сборник богословско-публицистических статей, документов и комментариев / общ. ред., сост. и комм. протоиерея К. Борщ. - М. : [б. и.], 2005.- C. 996-1043.

18. Сенина, Т. А. Последний византиец. Религиозно-философская мысль иеросхимонаха Антония (Булатовича) и ее византийский контекст / Т. А. Сенина. -СПб. : Дмитрий Буланин, 2013. - 448 с.

19. Сенина, Т. А. (монахиня Кассия). Тема обожения в русском богословии: вклад иеросхимонаха Антония (Булатовича) / Т. А. Сенина (монахиня Кассия) // Национальное своеобразие в философии : материалы межвузовской конференции, Москва, 8-9 дек. 2009 г. / отв. ред. А. Н. Круглов. - М. : РГГУ, 2009. - C. 117-124.

20. Сенина, Т. А. (монахиня Кассия). Учение об энергии Божией и проблема статуса божественного Откровения в произведениях иеросхимонаха Антония (Булатовича) / Т. А. Сенина (монахиня Кассия) // Записки Александрийского семинара. 2012. - Т. 2. - С. 60-76.

21. Творения преподобного Иоанна Дамаскина. Источник знания / пер. и коммент. Д. Е. Афиногенова [и др.]. - М. : Индрик, 2002. - 416 с. - (Святоотеческое наследие).

22. Alexander (Golitzin), hieromonk. Christian mysticism over Two Millenia / Alexander (Golitzin), hieromonk // Scrinium. Revue de patrologie, d'hagiographie critique et d'histoire ecclésiastique. 2006.-T. 3. - P. xxi-xxxiii. -DOI: https://doi.org/10.1163/ 18177565-90000147.

23. Cyrille d'Alexandrie. Dialogues sur la Trinité. 3 vols. Vol. II / éd. G. M. de Durand. - Paris : Cerf, 1977. - 470 p. - (Sources chrétiennes ; 237) ; Vol. III / éd. G. M. de Durand. - Paris : Cerf, 1978. - 332 p. (Sources chrétiennes ; 246).

24. Lampe, G. W. H. A patristic Greek lexicon / G. W. H. Lampe. - Oxford : Clarendon Press, 1961.$1616 \mathrm{p}$.

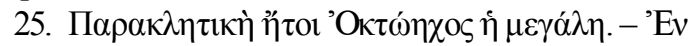

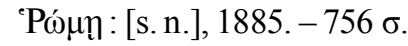

26. Senina, T. The Status of Divine Revelation in the Works of Hieromonk Anthony Bulatovich / T. Senina // Scottish Journal of Theology. - 2011. -
Vol. 64, Pt. 4. - P. 377-389. - DOI: https://doi.org/ 10.1017/S0036930611000202.

27. Sénina, T. (moniale Kassia). Un palamite russe du début du $X^{\text {ème }}$ siècle : Le hiéromoine Antoine Boulatovitch et sa doctrine sur l'énergie divine / T. Senina // Scrinium. Revue de patrologie, d'hagiographie critique et d'histoire ecclésiastique. 2010. - T. 6. - P. 392-409. - DOI: https://doi.org/10.1163/ $18177565-90000050$.

\section{REFERENCES}

1. Antoniy Bulatovich, hieromonk. Apologiya very vo Imya Bozhie $i$ vo Imya Iisus [Apology of Faith in the Name of God and in the Name of Jesus]. Moscow, Pech. A.I. Snegirevoy Publ., 1913. XIV. 189 p. (in Russian).

2. Antoniy Bulatovich, hieromonk. Moya mysl vo Khriste. O Deyatelnosti (Energii) Bozhestva [My Thought in Christ: On Activity (Energy) of the Godhead]. Petrograd, Ispovednik Publ., 1914. 248 p. (in Russian).

3. Antoniy Bulatovich, hieromonk. Opravdanie very $v$ Nepobedimoe, Nepostizhimoe, Bozhestvennoe Imya Gospoda nashego Iisusa Khrista [Apology of Faith in the Invincible, Incomprehensible, Divine Name of our Lord Jesus Chris]. Petrograd, Ispovednik Publ., 1917. 232 p. (in Russian).

4. Biryukov D.S. Sv. Grigoriy Bogoslov. Triadologiya i antiarianskaya polemika [St. Gregory the Theologian. Triadology and Controversy with Arianism]. Benevich G.I., Biryukov D.S., eds. Antologiya vostochno-khristianskoy bogoslovskoy mysli. Ortodoksiya i geterodoksiya [An anthology of Eastern Christian Theological Thought. Orthodoxy and Heterodoxy]. Moscow; Saint Petersburg, Nikea Publ., RKhGA Publ., 2009, vol. 1, pp. 291-301. (in Russian).

5. Biryukov D.S. Sv. Grigoriy Nisskiy [St. Gregory of Nyssa]. Benevich G.I., Biryukov D.S., eds. Antologiya vostochno-khristianskoy bogoslovskoy mysli. Ortodoksiya i geterodoksiya [An Anthology of Eastern Christian Theological Thought. Orthodoxy and Heterodoxy]. Moscow; Saint Petersburg, Nikea Publ., RKhGA Publ., 2009, vol. 1, pp. 397-405. (in Russian).

6. Grigoriy Palama. Triady v zashchitu svyashchenno-bezmolvstvuyushchikh [Gregory Palamas. Triads for the Defense of Those Who Practice Sacred Quietude]. Moscow, Kanon Publ., 1995. 384 p. (in Russian).

7. Dionysius the Areopagite. Sochineniya. Maksim Ispovednik. Tolkovaniya [Works. Maximus the Confessor. Commentaries]. Saint Petersburg, Oleg Abyshko Publ., 2002. 864 p. (in Russian). 
8. Ilarion (Alfeev), bishop. Svyashchennaya tayna Tserkvi. Vvedenie $v$ istoriyu i problematiku imyaslavskikh sporov [Sacred M+ystery of the Church: Introduction to the History and Background of the Onomatidoxy Controversy]. Saint Petersburg, Aletheia Publ., 2002, vol. 1. 653 p. (in Russian).

9. Leskin D., priest. Spor ob imeni Bozhiem. Filosofiya imeni $v$ Rossii v kontekste afonskikh sobytiy 1910-kh gg. [Dispute on the Name of God: Philosophy of Name in Russia in the context of the Events on Mt. Athos in the 1910s]. Saint Petersburg, Aletheia Publ., 2004. 368 p. (in Russian).

10. Lure V.M. Theophaneia School: Ekfrasis Nebesnogo Khrama [Theophaneia School: Ekphrasis of the Heavenly Temple]. Scrinium. Revue de patrologie, d'hagiographie critique et d'histoire ecclésiastique, 2006, vol. 3, pp. ix-xii. DOI: https:// doi.org/10.1163/18177565-90000147. (in Russian).

11. Meyendorf I. Zhizn i trudy svyatitelya Grigoriya Palamy [The Life and Works of St. Gregory Palamas]. Saint Petersburg, Vizantinorossika Publ., 1997. XVI. $480 \mathrm{p}$.

12. Oktoikh, sirech Osmoglasnik. Vol. 1. Voices 1-4. Moscow, Talan Publ., 1981. 712 p.; Vol. 2. Voices 5-8. Moscow, Talan Publ., 1981. 672 p. (in Russian).

13. Svyatitel Grigoriy Bogoslov, arkhiepiskop Konstantinopolskiy. Tvoreniya. V2 t. T. I [St. Gregory the Theologian. Works. In 2 vols. Vol. I]. Moscow, Sibirskya blagozvonnitsa Publ., 2010. 895 p. (in Russian).

14. Svyatitel Grigoriy Bogoslov, arkhiepiskop Konstantinopolskiy. Tvoreniya. V2 t. T. II [St. Gregory the Theologian. Works. In 2 vols. Vol. II]. Moscow, Sibirskaya blagozvonnitsa Publ., 2011. 944 p. (in Russian).

15. Dunaev A.G., ed. Svyatitel Grigoriy Palama, arkhiepiskop Fessalonikiyskiy. Polemika s Akindinom [St. Gregory Palamas. Controversy with Akindynos]. Holy Mountain Athos, Novaya Fivaida Publ., 2009. 270 p. (in Russian).

16. Svyatoe Pravoslavie i imenobozhnicheskaya eres [Holy Orthodoxy and the Heresy of NameIdolisers]. Kharkiv, Eparkh. tip. Publ., 1916, vol. IV, 278, XLII p. (in Russian).

17. Senina T. Imyaslavtsy ili imyabozhniki? Spor o prirode Imeni Bozhiya i afonskoe dvizhenie imyaslavtsev 1910-1920-kh godov ['Name-Praisers' or 'Name-Idolisers'? Dispute about the Nature of the Name of God and the Athonite Movement of 'NamePraising' Monks in the 1910s-1920s]. Borshch K., archpriest, ed. Imyaslavie. Sbornik bogoslovskopublitsisticheskikh statey, dokumentov $i$ kommentariev [Onomatodoxy: Collection of Theological and Journalistic Articles, Documents, and Commentaries]. Moscow, 2005, vol. 2, pp. 996-1043. (in Russian).
18. Senina T.A. Posledniy vizantiets. Religioznofilosofskaya mysl ieroskhimonakha Antoniya (Bulatovicha) i ee vizantiyskiy kontekst [The Last of the Byzantines. The Religious and Philosophical Thought of Hieromonk Anthony Bulatovich and Its Byzantine Context]. Saint Petersburg, Dmitriy Bulanin Publ., 2013. 448 p. (in Russian).

19. Senina T.A. (nun Kassia). Tema obozheniya v russkom bogoslovii: vklad ieroskhimonakha Antoniya (Bulatovicha) [The Theme of Deification in Russian Theology: the Contribution of Hieromonk Anthony Bulatovich]. Kruglov A.N., ed. Natsionalnoe svoeobrazie v filosofii. Materialy mezhvuzovskoy konferentsii, Moskva, 8-9 dekabrya 2009 g. [National Identity in Philosophy. Materials of the Inter-University Conference, Moscow, December 8-9, 2009]. Moscow, RGGU Publ., 2009, pp. 117-124. (in Russian).

20. Senina T.A. (nun Kassia). Uchenie ob energii Bozhiey i problema statusa bozhestvennogo Otkroveniya v proizvedeniyakh ieroskhimonakha Antoniya (Bulatovicha) [The Doctrine of the Energy of God and the Problem of the Status of Divine Revelation in the Works of Hieromonk Anthony Bulatovich]. Zapiski Aleksandriyskogo seminara [Notes of the Alexandria Seminar], 2012, vol. 2, pp. 6076. (in Russian).

21. Afinogenov D.E. [et al.], eds. Tvoreniya prepodobnogo Ioanna Damaskina. Istochnik znaniya [Works of Saint John of Damascus. Source of Knowledge]. Moscow, Indrik Publ., 2002. 416 p. (in Russian).

22. Alexander (Golitzin), hieromonk. Christian mysticism over Two Millenia. Scrinium. Revue de patrologie, d'hagiographie critique et d'histoire ecclésiastique, 2006, vol. 3, pp. xxi-xxxiii. DOI: https:// doi.org/10.1163/18177565-90000147.

23. de Durand G.M., ed. Cyrille d'Alexandrie. Dialogues sur la Trinité. In 3 vols. Vol. 2. Paris, Cerf, 1977. 470 p. (Sources chrétiennes; 237); Vol. III. Paris, Cerf, 1978. 332 p. (Sources chrétiennes; 246).

24. Lampe G.W.H. A patristic Greek lexicon. Oxford, Clarendon Press, 1961.1616 p.

25. Paraklētikè ètoi Oktōēhos è megalē [Parakletike, or The Great Octoechos]. Rome, 1885. 756 p. (in Greek).

26. Senina T. The Status of Divine Revelation in the Works of Hieromonk Anthony Bulatovich. Scottish Journal of Theology, 2011, vol. 64, part 4, pp. 377-389. DOI: https://doi.org/10.1017/S0036930611000202.

27. Sénina T. (nun Kassia). Un palamite russe du début du $\mathrm{XX}^{\text {ème }}$ siècle: le hiéromoine Antoine Boulatovitch et sa doctrine sur l'énergie divine. Scrinium. Revue de patrologie, d'hagiographie critique et d'histoire ecclésiastique, 2010, vol. 6, pp. 392-409. DOI: https://doi.org/10.1163/1817756590000050. 


\section{Information about the Author}

Tatyana A. Senina (nun Kassia), Candidate of Sciences (Philosophy), Senior Researcher, Sociological Institute of Russian Academy of Sciences - Branch of Federal Research Centre for Sociology of Russian Academy of Sciences, 7-ya Krasnoarmeyskaya St., 25/14, Saint Petersburg, 190005, Russian Federation,mon.kassia@gmail.com, https://orcid.org/0000-0001-8120-3499

\section{Информация об авторе}

Татьяна Анатольевна Сенина (монахиня Кассия), кандидат философских наук, старший научный сотрудник, Социологический институт РАН - филиал Федерального научно-исследовательского социологического центра, ул. 7-я Красноармейская, 25/14, г. Санкт-Петербург, 190005, Российская Федерация, mon.kassia@gmail.com, https://orcid.org/0000-0001-8120-3499 